\title{
Pengaruh Islamic Corporate Governance Terhadap Tax Avoidance Pada Bank Umum Syariah Di Indonesia
}

\author{
Metiya Fatikhatur Riziqiyah \\ Fakultas Ekonomi dan Bisnis, Universitas Jenderal Soedirman. \\ tiya.fr28@gmail.com \\ Bambang Agus Pramuka \\ Fakultas Ekonomi dan Bisnis, Universitas Jenderal Soedirman \\ bambang.pramuka@unsoed.ac.id
}

\begin{abstract}
Abstrak
Penelitian ini dilakukan untuk menguji apakah Islamic Corporate Governance yang diproksikan oleh dewan pengawas syariah, komite audit dewan komisaris independen, profitabilitas dan ukuran perusahaan dapat meminimalkan penghindaran pajak pada Bank Umum Syariah di Indonesia. Sampel bank syariah yang digunakan berjumlah 11 Bank Umum Syariah periode 2015-2019. Pemilihan sampel menggunakan metode purposive sampling. Pengujian hipotesis menggunakan analisis regresi berganda. Hasil penelitian menunjukan bahwa dewan pengawas syariah, komite audit dan proporsi komisaris independen berpengaruh negatif terhadap tax avoidance, sedangkan profitabilitas dan ukuran perusahaan berpengaruh positif terhadap tax avoidance.
\end{abstract}

Kata Kunci : Islamic Corporate Governance, Tax Avoidance, Banks Umum Syariah, Dewan Pengawas Syariah.

\section{The Influence of Islamic Corporate Governance Against Tax Avoidance in Islamic Commercial Banks in Indonesia}

\begin{abstract}
This research aimed to examine wether Islamic Corporate Governance proxied by the Sharia Supervisory Board, audit committee, proportion board of commissioners, profitabilitas and company size is able to minimize the tax avoidance of Islamic Banks in Indonesia. The sample of Islamic banks was used 11 Islamic Commercial Banks in the period 2015-2019. The sample was selected using a purposive sampling method. Multiple regression analysis is employed to test the hypotheses The results of this study show that sharia supervisory board, audit committee and proportion board of commissioner have a negative affect on tax avoidance, while profitability and company size have a possitive affect on tax avoidance.

Keyword : Islamic Corporate Governance, Tax Avoidance, Islamic Bank, Sharia Supervisory Board.
\end{abstract}

\section{PENDAHULUAN}

Pendapatan negara tertinggi salah satunya ditopang dari sektor perpajakan. Penerimaan pajak dipakai dalam pembiayaan belanja negara maupun untuk pembangunan negara. Pembayaran pajak yang tinggi dan lemahnya corporate governance mengakibatkan para wajib pajak melakukan upaya efisiensi pembayaran pajak, salah satunya dengan membayar pajak minimum tanpa melanggar hukum dengan penghindaran pajak secara legal. Perusahaan berusaha menekan pajak sekecil mungkin, sedangkan pemerintah menginginkan pajak semaksimal mungkin untuk membiayai penyelenggaraan pemerintahan, sehingga realisasi penerimaan pajak tidak sesuai dengan yang diharapkan dan tidak mencapai target yang ditetapkan (Arinta, 2018).

Dalam perbankan syariah, agama memainkan peranan penting karena semua kegiatan usahanya harus sesuai dengan prinsip dan etika bisnis syariah. Corporate governance bank syariah dan bank konvensional dibedakan dengan adanya Dewan Pengawas Syariah (Sharia Supervisory Board) dalam struktur 
corporate governance-nya, yang berfungsi memberikan nasihat dan masukan yang ditujukan kepada direksi serta mengawasi aktivitas bank supaya tidak keluar dari jalur prinsip-prinsip syariah.

(Trisasmita, 2018) hasil penelitianya menyatakan adanya dewan pengawas syariah berpengaruh secara signifikan terhadap Islamic Governance. Rachmitsari, 2015 menyatakan bahwa corporate governance tidak berpengaruh yang signifikan terhadap penghindaran pajak. Sementara penelitian (Vivi, 2016) menyatakan bahwa komite audit mempengaruhi penghindaran pajak secara parsial dan signifikan.

Bank Syariah di enam belas negara salah satunya Indonesia belum sempurna dalam mekanisme eksternal yang berkaitan dengan aturan dalam menjalankan good corporate governance perbankan syariah tidak dilaksanakan dengan baik dan diterapkan sesuai dengan prinsip syariah (Rini, 2018). Kasus tunggakan pajak yang dilakukan Bank Nasional Indonesia syariah pada tahun 2010 yang melakukan operasional usahanya tidak sesuai dengan prinsip syariah menunjukan bahwa adanya fenomena tidak syariahnya bank syariah.

(Darmadi, 2013) mengungkapkan adanya pemangku kepentingan yang beragam di bank syariah dijadikan tujuan utama bank syariah dalam mengungkap kegiatan tata kelola syariahnya secara tepat dan transparan. Kegiatan operasional perbankan syariah yang dijalankan berdasarkan prinsip-prinsip syariah seharusnya mampu menjadikan bank syariah tampil sebagai yang terdepan dalam mengimplementasikan good corporate governance (Gunawan dkk, 2018).

Berdasarkan uraian diatas menunjukan bahwa pentingnya system pengelolaan perusahaan yang tepat sangat diperlukan dan menjadi dasar bagi para pakar ekonomi islam untuk mengembangkan islamic corporate governance sebagai salah satu solusi dalam mengatasi kelemahan-kelemahan operasional perbankan syariah. Tantangan dan resiko yang dihadapi semakin rumit baik dari faktor internal maupun ekternal, yang berdampak pada kinerja perbankan secara nasional terutama perbankan syariah yang masih tergolong muda. Hal ini membuat peneliti tertarik untuk meneliti pengaruh islamic corporate governance yang diproksikan oleh dewan pengawas syariah, komisaris independen, komite audit, return on asset dan ukuran perusahaan terhadap tax avoidance. Dengan demikian dengan adanya penelitian ini diharapkan dapat memberikan kontribusi dalam membuat dan mengatur pengelolaan perusahaan sesuai dengan prinsip syariah sehingga dapat meminimalkan terjadinya penghindaran pajak.

\section{TINJAUAN PUSTAKA}

\section{Sharia Enterprise Theory}

Sharia Enterprise Theory menempatkan Allah sebagai dzat yang memberi amanah, dan stakeholder bertanggung jawab menggunakan aset tersebut sesuai dengan aturan dan ketentuan-ketentuan yang ditetapkan Allah. Nilai spiritual yang melekat dalam Sharia Enterprise Theory antara lain abduh, mardhatillah, dan rahmatan lil alamin (Triyuwono, 2015).

Konsep sharia enterprise theory merupakan teori yang menjelaskan bahwa tanggung jawab perusahaan tidak hanya terhadap para pemilik perusahaan tetepi juga seluruh stakeholder yang berkaitan dengan perusahaan, pemangku kepentingan yang meliputi Allah, manusia dan alam, (Puspitasari, 2017). Dengan adanya teori ini diharapkan pihak manajemen mematuhi prinsip-prinsip yang telah ditetapkan. Semakin bagus penerapan Islamic Corporate Governance memungkinkan Bank Umum Syariah semakin mawas diri dan bijak dalam melaksanakan tugasnya sehingga dapat meminimalisir kecurangan diantaranya tax avoidance. Informasi keuangan yang disajikan oleh perbankan syariah yang menerapkan syariah enterprise theory harus menyajikan semua informasi sesuai fakta dan dapat dipercaya, sehingga tidak menyesatkan para pengguna laporan keuangan yang diterbitkan oleh Bank Umum Syariah.

\section{Agency Theory}

Sistem tata kelola perusahaan merupakan suatu rancangan yang didasari pada teori keagenan, diharapkan dapat berfungsi sebagai alat untuk memberi keyakinan bahwa penanam modal akan menerima laba atas aset yang telah diinvestasikan (Gunawan,2019). Adanya perbedaan kepentingan antara pemilik perusahaan dengan stakeholder maka muncul adanya teori agency. (Jansen dan Meckling, 1976), secara detail mengungkapkan adanya hubungan keagenan antara manager perusahaan (agen) dengan pemegang saham (principal). Adanya perbedaan kepentingan antara agen dan principal dimana agen tidak selalu membuat keputusan-keputusan yang terbaik untuk principal sehingga menimbulkan munculnya asimetri informasi.

Dengan adanya agency theory, dewan pengawas syariah dapat dijadikan sebagai pihak yang dapat mengontrol, mengawasi dan memastikan bank sebagai management yang dapat dipercaya dalam mengelola organisasi dan bertindak untuk kepentingan seluruh stakeholder.

\section{Tax Avoidance}


(Pradita dan Putu, 2017) mendefinisikan bahwa tax avoidance sebagai suatu upaya yang dilaksanakan oleh perusahaan yang bertujuan untuk mengurangi jumlah beban pajak perusahaan. (Winata, 2014) menyatakan bahwa tax avoidance/penghindaran pajak sebagai penghindaran pajak yang dapat ditolelir oleh hukum yang berlaku. keagresifan penghindaran pajak dapat diditeksi melalui perhitungan cash effective tax (CETR). Metode ini mampu mengindikasikan adanya agresifitas dalam perencanaan pajak melalui perhitungan komponen rekonsialisasi fiskal, beda tetap maupun beda temporer. (Prasetyo dan Pramuka, 2018), memberikan definisi yang lebih komprehensif, dimana penghindaran pajak dianggap sebagai skema transaksi yang digunakan untuk meminimalkan beban pajak, dengan memanfaatkan kelemahan ketentuan perpajakan suatu negara, sehingga dapat dinyatakan legal oleh ahli pajak.

\section{Islamic Corporate Governance}

Tata kelola perushaan dalam perspektif islam menurut (hattii dan Bhatti 2010:27) dalam Rini (2018): mendefinisikan tata kelola perusahaan sebagai upaya untuk mencari cara di mana pelaku ekonomi, sistem regulasi, dan pengelolaan perusahaan dapat diarahkan oleh nilai-nilai moral dan sosial berdasarkan prinsip- prinsip syariah. Seluruh kegiatan ekonomi perusahaan, dan bisnis didasarkan pada paradigma etrhoreligious dengan tujuan tunggal yaitu kesejahteraan individu dan seluruh masyarakat. Pada dasarnya, tujuan ICG tidak jauh beda dengan corporate governance secara umum, namun ICG lebih berpegang teguh pada nilai-nilai Islam yang dipadukan dengan model stakeholder dalam corporate governance.

Karakteristik ICG menurut Larbsh (2015) dalam Hartono (2018) menyebutkan bahwa seluruh kegiatan, etika dan sosial perusahaan harus mempertimbangkan hukum syariah, prinsip ekonomi dan keuangan Islam pada praktek dan kebijakan, misalnya pada lembaga zakat, larangan spekulasi dan riba, serta pengembangan sistem ekonomi yang didasarkan pada bagi hasil. Tujuan utama Islamic Corporate Governance adalah Maqasid Shariah yang merujuk pada kesejahteraan masyarakat (Endraswati, 2015).

\section{Pengaruh Dewan Pengawas Syariah terhadap Tax avoidance}

Mekanisme pengelolaan perusahaan perbankan syariah yang membedakan dengan bank konvensional adalah adanya Dewan Pengawas Syariah (DPS) yang merupakan badan eksternal yang independen. Salah satu peran penting dari DPS diantaranya menentukan tingkat kepercayaan bank syariah, yang merupakan bagian terpenting dalam pelakasanaan Corporate Governance (GCG) dan menciptakan adanya kepatuhan syariah (Chariri 2012). Semakin tinggi tingkat pengawasan dewan pengawas syariah, membuat para pemegang kepentingan melakukan pengungkapan laporan yang benar sesuai prinsip syariah, sehingga tax avoidance dapat diminimalisir.

Menurut Salman, dkk (2018) menyatakan bahwa DPS mempunyai pengaruh terhadap tinggi rendahnya praktik tax avoidance yang dilakukan perusahaan. Dengan jumlah anggota dewan pengawas syariah yang banyak maka semakin baik kemampuannya dalam mengontrol dan mengawasi semua aktivitas kegiatan pada perbankan syariah sehingga berpengaruh pada kualitas pengungkapan laporan keuangan yang baik pula.

Dalam penelitian Sula, dkk (2014) keberadaan dewan pengawas syariah sangat penting sebagai badan penyeimbang yang mengawasi segala bentuk kegiatan operasional bank syariah, sehingga perlu dukungan dan fasilitas yang memadai untuk membantu memaksimalkan peran, fungsi, dan tanggung jawabnya, sehingga masih kurangnya dukungan fasilitas terhadap dewan pengawas syariah mengakibatkan perusahaan melakukan tax avoidance.

Semakin banyak anggota DPS maka akan semakin efektif monitoring dan konsistensi pada prinsip syariah, sehingga semakin besar kemampuannya dalam mengontrol transaksi pada perbankan syariah dengan melihat kesesuaiannya dengan prinsip syariah yang berpengaruh pada kualitas pengungkapan (Arinta,2018). Hipotesis penelitiannya adalah :

\section{H1: Dewan pengawas syariah berpengaruh negatif terhadap tax avoidance}

\section{Pengaruh Komite Audit terhadap Tax Avoidance}

Tugas dan tanggung jawab yang dimiliki komite audit tidak jauh berbeda dengan dewan pengawas syariah. Winata (2014) mengungkapkan bahwa komite audit yang mempunyai tugas membantu memeriksa dan meneliti pelaksanaan fungsi direksi dalam mengelola perusahaaan dibentuk oleh dewan komisaris perusahaan, yang anggotanya diangkat dan diberhentikan oleh dewan komisaris.

Menurut Asri dan Suardana (2016) dalam penelitiannya memaparkan bahwa dengan adanya komite audit di perusahaan sangat membantu dewan komisaris dalam menjalankan tugasnya memonitor manajemen perusahaan dalam penyusunan laporan keuangan perusahaan. Gunawan (2019) menyatakan hasil yang sama 
bahwa komite audit membantu dewan komisaris dalam mengawasi kinerja perusahaan, maka dengan adanya komite audit dapat mencegah perusahaan tersebut melakukan tindakan tax avoidance. Dengan meningkatnya jumlah komite audit maka praktik tax avoidance semakin menurun. Berbeda dengan penelitiaan yang dilakukan oleh Sandy dan Lukviarman (2015) yang menyatakan bahwa komite audit mempunyai pengaruh negatif dan signifikan terhadap tax avoidance.

\section{H2 : Komite audit berpengaruh negatif terhadap tax avoidance}

\section{Pengaruh Proporsi Komisaris Independen terhadap Tax Avoidance}

Komisaris independen merupakan dewan komisaris yang kedudukannya tidak dipengaruhi apapun atau independen, tidak merupakan pemegang saham mayoritas, dan tidak ada hubungan dengan pemegang saham pengendali. Semakin banyak komisaris independen pada perusahaan akan semakin tinggi tingkat independensi perusahaan sehingga kegiatan melakukan tax avoidance akan semakin rendah.

Adanya komisaris independen yang diukur dengan menggunakan persentase dewan komisaris yang ada dalam suatu perusahaan dapat menunjang kinerja perusahaan dan meningkatkan efektifitas pengawasan. Sandi dan Lukviarman (2015) hasil penelitianya menyatakan bahwa komisaris independen berpengaruh signifikan negatif terhadap tax avoidance. Peneliatian Raharjo dan Daljono (2014), menyatakan bahwa peluang terjadinya kecurangan dalam manajemen dapat diminimalisir dengan adanya komisaris independen dengan proporsi yang besar sehingga dapat melakukan pengawasan secara maksimal. Hasil yang sama diperoleh dari penelitian yang dilakukan oleh Dewi dan Jati (2014) serta penelitian Prakosa (2014), keduanya menyatakan bahwa dewan komisaris independen memberikan pengaruh negatif terhadap tax avoidance. Sehingga hipotesisnya adalah :

\section{H3 : Proporsi komisaris independen berpengaruh negatif terhadap tax avoidance}

\section{Pengaruh Profitabilitas terhadap Tax Avoidance}

Profitabilitas merupakan kemampuan perusahaan dalam meenghasilkan laba yang dalam penelitian ini ini diukur menggunakan Return On Asset (ROA). Hasil penelitian Husna dan Fajriyana (2018) menyatakan bahwa ukuran perusahaan, profitabilitas, dan kepemilikan institusional berpengaruh terhadap tax avoidance. Surbakti (2012) menyatakan profitabilitas perusahaan memiliki hubungan positif pada penghindaran pajak jika perusahaan yang berupaya menghindari pajak maka kinerjanya harus efisien agar kewajiban pajak tidak terlalu tinggi

\section{H4 : Profitabilitas berpengaruh positif terhadap tax avoidance}

\section{Pengaruh Ukuran Perusahaan terhadap Tax Avoidance}

Ukuran perusahaan merupakan salah satu variabel yang banyak digunakan untuk menjelaskan mengenai variasi pengungkapan dalam laporan tahunan perusahaan. Semakin besar perusahaan semakin mudah masyarakat memperoleh informasi tentang perusahaan sehingga dapat menentukan tingkat kepercayaan investor. Ukuran perusahaan, struktur hutang dan total aset yang digunakan sebagai proksi untuk mengukur karakteristik perusahaan yang dapat mendeteksi terjadinya tax avoidance. Besar kecilnya total aset yang dimiliki perusahaan juga dapat mempengaruhi peluang penrusahaan untuk melakukan tax avoidance. Sehingga hipotesisnya:

H5 : Ukuran perusahaan berpengaruh positif terhadap tax avoidance

\section{METODE PENELITIAN}

\section{Rancangan Penelitian}

Jenis penelitian ini adalah kuantitatif dengan sumber data sekunder dari laporan keuangan tahunan Bank Umum Syariah yang terdafatar di Otoritas Jasa Keuangan melalui website masing-masing bank. Penelitian ini menggunakan varibael independen dan variabel dependen. Dalam pengukuran Islamic Corporate Governance menggunakan proksi dewan pengawas syariah, komite audit dan proporsi komisaris independen, dari variabel kinerja perusahaan menggunakan profitabilitas yang diukur menggunakan Return On Aset dan dari variabel kriteria perusahaan menggunakan ukuran perusahaan.

\section{Populasi dan Sampel}

Populasi dalam penelitian ini adalah seluruh Bank umum Syariah yang ada di Indonesia dari tahun 2015 sampai tahun 2019 ada 11 bank umum syariah terdiri dari Bank BCA Syariah, Bank BNI Syariah, 
Bank BRI Syariah, Bank Jabar Banten Syariah, Bank Maybank Syariah Indonesia, Bank Muamalat Indonesia, Bank Panin Dubai Syariah, Tbk, Bank Syariah Bukopin, Bank Syariah Mandiri, Bank Mega Syariah, Bank Victoria Syariah.

Penelitian ini menggunakan sampel seluruh Bank Umum Syariah di Indonesia yang melaporkan laporan keuangan tahunan (annual report) dari tahun 2015 sampai 2019. Teknik pengambilan sampel menggunakan metode purposive sampling. Adapun kriteria sampel yang digunakan adalah Bank Umum Syariah yang ada di Indonesia dan mempublikasikan laporan keuangan dari tahun 2015-2019 dengan menggunakan mata uang rupiah.

\section{Definisi dan Pengukuran Variabel}

Pada penelitian ini terdapat 6 variabel yakni satu variabel dependen yaitu tax avoidance, dan lima variabel independen yakni Dewan Pengawas Syariah, Komite Audit, Proporsi Komisaris Independen , Profitabilitas, Ukuran Perusahaan.

\section{Tax Avoidance}

Pengukuran variable yang digunakan dalam penghindaran pajak adalah Cash Effective Tax Rate (CETR) dengan menggunakan formula (Hanlon \& Heitzman, 2010):

\section{CETR $=\underline{\text { Cash } \text { Tax Paid }}$ \\ Pre - Tax Income}

Keterangan :

CETR

$$
\text { = Cash Effective Tax Rate }
$$

Cash Tax Paid = Pajak yang dibayarkan perusahaan

Pre-Tax Income = Laba sebelum pajak

\section{Dewan Pengawas Syariah}

Menurut Peraturan Bank Indonesia Nomor 6/24/PBI/2004 pasal 26 (1) menyatakan bahwa jumlah anggota Dewan Pengawas Syariah paling kurang 2 (dua) orang dan sebanyak-banyaknya 5 (lima) orang.

\section{JDPS $=\Sigma$ Dewan Pengawas Syariah \\ Jumlah Komite Audit}

Ukuran Komite Audit merupakan jumlah seluruh anggota Komite Audit yang terdapat di perusahaan (Felo et al., 2003). PBI Nomor: 11/33/PBI/2009 mengatur bahwa jumlah anggota komite audit minimal tiga orang anggota, terdiri dari satu komisaris independen perusahaan yang merangkap sebagai ketua komite audit, dan dua anggota yang merupakan pihak ekstern independen di mana satu diantaranya memiliki keahlian di bidang keuangan atau perbankan.

\section{$J K A=\Sigma$ Komite Audit dalam setahun}

\section{Proporsi Komisaris Independen}

Prasetyo dan pramuka (2018) berpendapat bahwa dewan komisaris independen yaitu dewan komisaris yang bukan merupakan anggota manajemen dan tidak memiliki modal saham terbanyak dalam perusahaan tersebut. Komisaris independen merencanakan strategi jangka panjang perusahaan dan secara berkala melakukan pengkajian startegi tersebut dan meminimalisir tindakan penghindaran pajak.

$$
\text { Proporsi KI }=\frac{\sum \text { Komisaris Independen }}{\sum \text { Anggota Komisaris }} \times 100 \%
$$

\section{Profitabilitas}

Menurut Hanafi (2009), profitabilitas merupakan kemampuan perusahaan yang dijadikan sebagai ukuran dalam menghasilkan keuntungan dari semua aset yang dimiliki oleh perusahaan. Penelitian ini 
menggunakan return on asset (ROA) untuk mengukur tingkat profitabilitas perusahaan, karena dengan ROA dapat dilihat bagaimana efektifitas perusahaan dalam mengelola aktiva baik modal sendiri maupun modal dari luar. Semakin banyak return on asset yang diterima, semakin tinggi keuntungan perusahaan sehingga semakin baik pengelolaan aset perusahaan (Lisa, 2016).

\section{Ukuran Perusahaan}

$$
\text { ROA }=\frac{\text { Laba bersih setelah pajak }}{\text { Total aktiva }} \times 100 \%
$$

Ukuran perusahaan memainkan peran dalam praktek penghindaran pajak, karena semakin besar ukuran perusahaan yang diukur dengan jumlah aset, maka beban perusahaan juga semakin besar, salah satu beban tersebut adalah beban pajak perusahaan. Semakin besar ukuran perusahaan maka perusahaan akan melakukan tindakan penghindaran pajak yang lebih besar (Tendean, 2016).

\section{Teknik Analisis Data}

Pengujian hipotesis dilakukan dengan model analisis linier berganda dengan tujuan untuk memprediksi kekuatan pengaruh variabel independen terhadap variabel dependen (Ghozali,2011). Dengan persamaan sebagai berikut :

$$
\mathrm{Y}=\mathbf{a}+\text { b1 DPS + b2 KA + b3 PKI + b4 ROA + b5 SIZE + e }
$$

Pengujian hipotesis dengan melihat nilai $\mathrm{t}$ untuk melihat signifikansi pengaruh variabel independen terhadap variabel dependen. Apabila nilai signifikansi t lebih kecil dari derajat kepercayaannya yaitu 5\%, maka pengaruh variabel independen terhadap variabel dependen adalah signifikan. Model yang baik menurut Ghozali (2005) dapat dilihat berdasarkan nilai adjusted $\mathrm{R}$ squared, nilai t dan nilai F. Sebelum dilakukan pengujian hipotesis, dilakukan pengujian asumsi klasik. Uji asumsi klasik yang meliputi uji normalitas, uji multi kolinearitas, uji heterokedastisitas, dan uji autokorelasi perlu dilakukan terlebih dahulu sebelum analisis data dilakukan (Ghozali, 2005:56).

\section{HASIL DAN PEMBAHASAN}

\section{Statistik Deskriptif}

Secara keseluruhan terdapat 55 data observasi perbankan selama tahun 2015-2019. Jumlah bank yang menjadi sampel penelitian ini berjumlah 11 bank umum syariah. sehingga semua populasi yang ada digunakan menjadi sampel dalam penelitian ini, sehingga sampel dalam penelitian ini merupakan sampel jenuh.

\section{Tabel 1. Hasil Uji Statistik Deskriptif

\begin{tabular}{|c|c|c|c|c|c|c|}
\hline & $\mathrm{N}$ & Minimum & Maximum & Mean & & Std. Deviation \\
\hline & Statistic & Statistic & Statistic & Statistic & Std. Error & Statistic \\
\hline$\overline{\text { CETR }}$ & 36 & -.04080 & 4.90625 & .5621901 & .17476421 & 1.04858523 \\
\hline DPS & 36 & 2 & 3 & 2.39 & .082 & .494 \\
\hline UKA & 36 & 2 & 7 & 3.78 & .211 & 1.267 \\
\hline PKI & 36 & .333 & 1.000 & 60787 & .029632 & .177795 \\
\hline ROA & 36 & -.1123 & .0180 & -.001282 & .0039451 & .0236703 \\
\hline SIZE & 36 & 29.240 & 32.352 & 30.48846 & .171054 & 1.026324 \\
\hline $\begin{array}{l}\text { Valid N } \\
\text { (listwise) }\end{array}$ & 36 & & & & & \\
\hline
\end{tabular} \\ Descriptive Statistics}

Sumber : data diolah, 2020 
Berdasarkan hasil uji statistik deskriptif pada tabel 1. dapat diketahui bahwa jumlah rata-rata Dewan Pengawas Syariah sebesar 2.39 jumlah minimal 2 orang dan maksimal 3 orang. Sesuai yang dinyatakan dalam Peraturan Bank Indonesia tahun 2004 bahwa jumlah anggota Dewan Pengawas Syariah sekurang-kurangnya dua orang dan sebanyak-banyaknya lima orang. Ukuran Komite Audit pada perbankan syariah di Indonesia dengan nilai rata-rata sebesar 3,78. Sesuai dengan yang diatur dalam Peraturan Bank Indonesia Nomor: 11/33/PBI/2013 bahwa keanggotaan Komite Audit sekurangkurangnya berjumlah 3 orang.

Proporsi Komisaris Independen pada perbankan syariah di Indonesia rerata $60,78 \%$. Regulasi di Indonesia khususnya GCG tentang Bank Syariah yaitu PBI Nomor 8/4/2006 pasal 5 menyatakan bahwa Dewan Komisaris terdiri dari Komisaris dan Komisaris Independen paling kurang 50\% (lima puluh perseratus) dari jumlah anggota Dewan Komisaris adalah Komisaris Independen. Hal ini menunjukkan bahwa proporsi Komisaris Independen pada perbankan syariah sudah sesuai dengan aturan yang berlaku. Pada variabel dependen yaitu tax avoidance memiliki nilai rata-rata (mean) sebesar 0.5621, nilai minimum sebesar -0.0408 , nilai maksimum sebesar 4.9062 dan standar deviasi sebesar 1.0485 .

\section{Uji Asumsi Klasik}

a. Uji Normalitas

Berdasarkan hasil uji kolmogorov smirnov setelah casewise diagnotics diketahui bahwa nilai probabilitas $>$ taraf signifikansi yang ditetapkan (alpa $=0.05$ ) yaitu 0,200 sehingga dapat diambil kesimpulan bahwa nilai residual data terdistribusi normal.

b. Uji Multikolinieritas

Hasil pengujian menunjukan bahwa keseluruhan variabel independen dewan pengawas syariah, komite audit, proporsi komisaris independen, profitabilitas dan ukuran perusahaan, memiliki nilai tolerance $(0.803 ; 0.565 ; 0,935 ; 0,893 ; 0,581)>1$ dan nilai VIF $(1,245 ; 1.769 ; 1,069 ; 1,120 ; 1,722)<10$, dapat diartikan bahw tidak terjadi multikolinearitas pada penelitian ini.

c. Uji Autokorelasi

Hasil uji durbin-watson menunjukkan nilai dl 1,3663 > nilai DW 1,354 < nilai du 1,663 maka terjadi autokorelasi. Oleh karena itu, dilakukan uji runs test untuk mengatasi autokorelasi dan menunjukkan nilai signifikansi 0,356 > 0,05 maka tidak terjadi autokorelasi.

d. Uji Heterokedastisitas

Berdasarkan uji glejser menunjukkan bahwa semua variabel memiliki signifikansi lebih besar dari 0,05 maka dapat diambil kesimpulan bahwa tidak terjadi heterokedastisitas dalam model regresi ini.

\section{Analisis Regresi Linier Berganda}

a. Uji Koefisien Determinasi

Tabel 2. Hasil uji koefisien determinasi

Model Summary

\begin{tabular}{lrrrr}
\hline Model & R & R Square & $\begin{array}{l}\text { Adjusted R } \\
\text { Square }\end{array}$ & \multicolumn{2}{l}{$\begin{array}{l}\text { Std. Error of the } \\
\text { Estimate }\end{array}$} \\
\hline 1 & $.576^{\mathrm{a}}$ & .332 & .242 & .23736364 \\
\hline
\end{tabular}

Sumber : data diolah, 2020

Uji koefisien determinasi menunjukkan bahwa nilai adjusted $R$ square sebesar 0,242 atau 24,2\%. Hasil ini menjelaskan bahwa variabel independen dewan pengawas syariah, Komite Audit (X2), Proporsi komisaris independen, profitabilitas dan Ukuran perusahaan dapat mempengaruhi variabel dependen tax avoidance (Y) sebesar 24,2\% dan sisanya dipengaruhi variabel lain. 
b. Uji F

Hasil uji F menunjukkan bahwa nilai sig. 0,008 < 0,05 maka variabel independen secara simultan mempengaruhi variabel dependen dan model regresi sudah tepat digunakan dalam penelitian ini.

c. Hasil Pengujian t statistik

\section{Coefficients $^{\mathrm{a}}$}

Tabel 3 : Hasil Uji t

\begin{tabular}{|c|c|c|c|c|c|c|c|}
\hline \multirow{3}{*}{$\begin{array}{l}\text { Model } \\
1 \text { (Constant) }\end{array}$} & \multicolumn{3}{|c|}{ Unstandardized Coefficients } & \multicolumn{2}{|c|}{$\begin{array}{l}\text { Standardized } \\
\text { Coefficients }\end{array}$} & & \multirow[b]{2}{*}{ ig. } \\
\hline & $\mathrm{B}$ & & Std. Error & Beta & & & \\
\hline & & -3.793 & 1.338 & & & -2.834 & .007 \\
\hline DPS & & -.002 & .084 & & -.004 & -.029 & .977 \\
\hline $\mathrm{KA}$ & & -.038 & .040 & & -.173 & -.970 & .339 \\
\hline PKI & & -.328 & .214 & & -.213 & -1.531 & .134 \\
\hline ROA & & 2.899 & 1.779 & & .232 & 1.629 & .112 \\
\hline SIZE & & .147 & .047 & & .552 & 3.129 & .003 \\
\hline
\end{tabular}

Berdasarkan analisis regresi linier berganda maka model regresi yang dibentuk dalam penelitian ini adalah sebagai berikut:

$$
\mathrm{CETR}=-3,793-0,002 \mathrm{DPS}-0,038 \mathrm{KA}-0,328 \mathrm{PKI}+2,899 \mathrm{ROA}+0,147 \mathrm{SIZE}+\mathrm{e}
$$

Keterangan :

$\begin{array}{ll}\text { CETR } & =\text { Penghindaran pajak } \\ \text { DPS } & =\text { Ukuran Dewan Pengawas Syariah } \\ \text { KA } & =\text { Komite Audit } \\ \text { PKI } & =\text { Proporsi Komisaris Independen } \\ \text { ROA } & =\text { Return On Asset } \\ \text { SIZE } & =\text { Ukuran Perusahaan } \\ \text { e } & =\text { Eror term }\end{array}$

Berdasarkan hasil uji t diperoleh hasil penelitian sebagai berikut:

a. Pengaruh Dewan Pengawas Syariah terhadap Tax Avoidance

Nilai koefisien regresi Dewan Pengawas Syariah -0,002 dengan arah negatif dan nilai signfikansi $0,977>0,05$ artinya bahwa setiap penambahan dewan komisaris (X1) maka tax avoidance akan menurun sebesar 0.012 .

b. Pengaruh Komite Audit terhadap Tax Avoidance

Berdasarkan uji t dapat diketahui bahwa nilai koefisien regresi komite audit -0,038 dengan arah negatif dan nilai signfikansi 0,339>0,05 artinya bahwa setiap penambahan komite audit (X2) maka tax avoidance akan menurun sebesar 0.038 .

c. Pengaruh Proporsi Komisaris Independen terhadap Tax Avoidance

Berdasarkan uji t dapat diketahui bahwa nilai koefisien regresi proporsi komisaris independen 0,328 dengan arah negatif dan nilai signfikansi $0,134>0,05$ artinya artinya bahwa setiap penambahan proporsi komisaris independen (X3) maka tax avoidance akan menurun sebesar 0.328. 
d. Pengaruh Profitabilitas terhadap Tax Avoidance

Berdasarkan uji t dapat diketahui bahwa nilai koefisien regresi profitabilitas 2,899 dengan arah positif dan nilai signfikansi $0,112>0,05$ artinya bahwa setiap penambahan profitabilitas maka tax avoidance akan meningkat sebesar 2.899

e. Pengaruh Ukuran Perusahaan terhadap Tax Avoidance

Berdasarkan uji t dapat diketahui bahwa nilai koefisien regresi ukuran perusahaan 0,147 dengan arah positif dan nilai signfikansi $0,003<0,05$ artinya bahwa semakin besar ukuran perusahaan maka tax avoidance akan meningkat sebesar 0.147 .

\section{KESIMPULAN}

Berdasarkan penelitian yang dilakukan menunjukan hasil bahwa islamic corporate governance dengan proksi dewan pengawas syariah, komite audit dan proporsi dewan komisaris mempunyai pengaruh negatif terhadap tax avoidance pada Bank Umum Syariah di Indonesia. Hasil ini menunjukan bahwa dari ketiga proksi tersebut sudah berhasil melakukan tugasnya sehingga dapat mencegah terjadinya tax avoidance. Sedangkan dari proksi profitabilitas dan ukuran perusahaan mempunyai pengaruh positif terhadap tax avoidance yang berarti bahwa tingkat profitabilitas yang tingggi dengan ukuran perusahaan yang semakin besar akan memberikan peluang besar untuk melakukan tax avoidance.

Penelitian ini masih memiliki keterbatasan sehingga untuk penelitian selanjutnya diharapkan menambah variabel lain yang bisa dijadikan proksi dalam penghindaran pajak. Menggunakan objek lain, tidak hanya perbankan syariah yang ada di Indonesia tetapi perbankan syariah di Asia.

\section{DAFTAR PUSTAKA}

Asri, Ida Ayu Trisna Yudi, and Ketut Alit Suardana. 2016. Pengaruh Proporsi Komisaris Independen, Komite Audit, Preferensi Risiko Eksekutif Dan Ukuran Perusahaan Pada Penghindaran Pajak. E-Jurnal Akuntansi Universitas Udayana Vol.16 No.1 72-100.

Bhatti, M. and Bhatti,I.(2010). Toward understanding Islamiccorporate governance issues in Islamic finance, Asian Politics and Policy. Vol. 2 No. 2, pp. 25-38.

Dewi, Ni Nyoman Kristiana dan I Ketut Jati. 2014. Pengaruh Karakter Eksekutif, Karakteristik Perusahaan, dan Dimensi Tata Kelola Perusahaan Yang Baik pada Tax Avoidance di Bursa Efek Indonesia. Jurnal.Fakultas Ekonomi dan Bisnis Universitas Udayana, Bali, Indonesia

Endraswati, H. (2017). Struktur Islamic Corporate Governance Dan Kualitas Pengungkapan Laporan Keuangan Pada Bank Syariah Di Indonesia Perspektif Governance dan Finance.

Endraswati, Hikmah. 2016. Konsep Awal Islamic Corporate Governance: Peluang Penelitian yang Akan Datang. Muqtashid.

Ghozali, I. 2016. Aplikasi Analisis Multivariate dengan Program IBM SPSS, Edisi Kedelapan. Badan Penerbit Universitas Diponegoro : Semarang

Husna, Nur, dan Icha Fajriyana. (2018). Pengaruh Ukuran Perusahaan, Profitabilitas, Kepemilikan Institusional, Komisaris Independen Dan Komite Audit Terhadap Tax Avoidance .

Hanlon, Michelle., \& Heitzman, Shane. 2010. A review of tax research. Journal of Accounting and Economics

Jensen, Michael C. dan W.H. Meckling. (1976). Theory of The Firm: Managerial Behavior, Agency Cost and Ownership Structure. Journal of Financial Economics 3. Hal. 305-360.

Kurniasih, N. A. (2012). Pengaruh Corporate Governance Terhadap Tax Avoidance . Jurnal akuntansi dan Auditing, 95-189.

Larbsh MM. (2015). Islamic Perspective of Corporate Governance. Acounting Department. Faculty of Economic and Commerce. Al-Asmarya Islamic University. 
Moeljono, 2019. Faktor-faktor yang Mempengaruhi Penghindaran Pajak. Jurnal Penelitian Ekonomi dan Bisnis, 5 (1), 2020, Hal: 103 - 121.

Matoussi, H and Grassa, R. (2012). Corporate Governance Different For Islamic Banks A Comparative Analysis Between The Gulf Cooperation Council Context And The Southeast Asia Context. The Economic Research Forum (ERF). 21 Al-Sad Al-Aaly Street Dokki, Giza Egypt.

Prasetyo, Irwan, dan Pramuka. 2018. Pengaruh Kepemilikan Institutional, Kepemilikan Manajerial, dan Proporsi Dewan Komisaris Independen Terhadap Tax Avoidance. Jurnal Ekonomi, Bisnis, dan Akuntansi (JEBA) Vol 20 No 02.

Praditasari, Ni Koming Ayui, dan Putu Ery Setiawan. 2017. Pengaruh Good Corporate Governance, Ukuran Perusahaan, Leverage dan Profitabilitas Pada Tax Avoidance. E-Jurnal Akuntansi Universitas Udayana Vol.19 No.2 1240.

Prakosa, Kesit Bambang. 2014. Pengaruh Profitabilitas, Kepemilikan Keluarga, dan Corporate Governance terhadap Penghindaran Pajak di Indonesia. Simposium Nasional Akuntansi XVII. Mataram

Rodriguez, E., F. dan Arias, A., M. 2013. Do Business Characteristics Determinean Effective Tax Rate. The Chinese Economy. 45 (6).

Rini,Nova, 2018. The Implementation of Islamic Corporate Governance (ICG) on Sharia Banking in Indonesia. The International Journal Of Applied Business Tijab, Volume 2 Nomor 1, April 2018

Sandy, Syeldila, and dan Niki Lukviarman. 2015. Pengaruh Corporate Governance Terhadap Tax Avoidance: Studi Empiris Pada Perusahaan Manufaktur.JAAI, Vol.19 No.2 85-98.

Surbakti, Theresa Adelina. 2012. Pengaruh Karakteristik Perusahaan dan Reformasi Perpajakan Terhadap Penghindaran Pajak di Perusahaan Manufaktur. Universitas Indonesia

Tandean, V. A., \& Winnie. (2016). The Effect of Good Corporate Governance on Tax Avoidance: An Empirical Study on Manufacturing Companies Listed in IDX period 2010-2013. Asian Journal of Accounting Research Vol 1 (2016) 8 - 15.

Triyuwono, Iwan. (2007). Perspektif, Metodologi, dan Teori Akuntansi Syariah. Jakarta : PT. Raja Grafindo Persada.

Winata. (2014). Pengaruh Corporate Governance Terhadap Tax Avoidance Pada Perusahaan Yang Terdaftar Di Bursa Efek Indonesia Tahun 2013. Tax and Accounting Review, Vol. 4, No. 1, Hal: 1-11. Universitas Kristen Petra. 